\title{
Isolated adipocytes from growth hormone-treated obese (ob/ob) mice exhibit insulin resistance
}

\author{
Peter Roupas, Roberto J. Towns and Jack L. Kostyo \\ Department of Physiology, The University of Michigan Medical School, Ann Arbor, MI (U.S.A.) \\ (Received 19 September 1989) \\ (Revised manuscript received 25 January 1990)
}

Key words: Insulin resistance; Growth hormone; (ob/ob Mouse); (Adipocyte)

\begin{abstract}
The genetically obese (ob/ob) mouse is a useful model for the study of the diabetogenic action of growth hormone (GH), because treatment of these animals with GH results in decreased responsiveness of their adipose tissue to insulin in vitro. Studies of the mechanisms involved in $\mathbf{G H}$-induced insulin resistance using isolated adipocytes of ob/ob mice have not been possible, however, because of their extreme fragility and the lack of an adequate system for the maintenance of these cells. This study describes a new method for the isolation of ob/ob mouse adipocytes. The isolated cells are stable, viable and metabolically responsive to insulin. In addition, these adipocytes have been maintained in primary culture, in serum-free medium, for up to 3 days. During culture, the cells exhibit large increases in ${ }^{125} \mathrm{I}$-hGH binding (10-20-fold) and porcine ${ }^{125}$ I-insulin binding (5-10-fold). The induction of insulin resistance by GH has also been demonstrated in these freshly isolated ob / ob mouse adipocytes. The studies to date indicate that the ob /ob mouse adipocyte system should provide a useful model for detailed studies of the cellular and molecular mechanisms of $\mathbf{G H}$ induced insulin resistance.
\end{abstract}

The genetically obese (ob/ob) mouse serves as a useful model for the study of the diabetogenic action of $\mathrm{GH}$, because, unlike normal rodents, it responds predictably to this anti-insulin effect of the hormone [1]. For example, treatment of ob/ob mice with either native or biosynthetic $\mathrm{GH}$ has been shown to result in increased hyperglycemia and glucose intolerance [2]. Also, treatment of ob/ob mice with reduced and $S$ carboxymethylated human growth hormone (RCM$\mathrm{hGH}$ ), a diabetogenic derivative of hGH lacking significant insulin-like or growth-promoting activities, resulted in a 3-fold increase in plasma insulin concentration and a decreased responsiveness of adipose tissue segments to insulin in vitro [1]. This induction of insulin resistance in adipose tissue, is not observed until $6 \mathrm{~h}$ after injection of the hormone [3]. The development of insulin resistance, however, could not be demonstrated in isolated $\mathrm{ob} / \mathrm{ob}$ mouse adipocytes [1]. It has not been

\footnotetext{
Abbreviations: GH, growth hormone; RCM-hGH S-carboxymethylated human growth hormone; DMEM, Dulbecco's modified Eagle's medium.
}

Correspondence: P. Roupas, Department of Physiology, Box 0622, The University of Michigan Medical School, Ann Arbor, MI 48109, U.S.A. possible to reproduce these in vivo effects of GH with $\mathrm{GH}$ in vitro, as attempts to maintain ob/ob mouse adipose tissue segments over extended periods of time have shown that the tissue deteriorates in vitro and looses its responsiveness to insulin [3]. Studies of the mechanisms involved in $\mathrm{GH}$-induced insulin resistance in isolated ob/ob mouse adipocytes have therefore previously not been possible, primarily because of the extreme fragility of these adipocytes, and the lack of an adequate system for the maintenance of these cells.

Recently, a method has been described for the isolation of rat adipocytes by mild digestion and for the maintenance of these cells in primary culture for several days [4]. This system has been used successfully for studies on the regulation of the insulin receptor [4] and for studies on the intracellular processing of $\mathrm{GH}$ and its receptor [5-8]. The objective of this study therefore, was to evaluate this method for the isolation and primary culture of ob/ob mouse adipocytes with a view to establishing a system in which the cellular mechanisms of $\mathrm{GH}$ induced insulin resistance could be studied.

Biosynthetic methionyl-hGH (Somatonorm ${ }^{\circledR}$ ) was used for the preparation of RCM-hGH as previously described [9]. The growth-promoting, diabetogenic, and insulin-like effects of RCM-hGH have previously been reported [9]. Genetically obese (ob/ob) female mice 
$(\mathrm{C} 57 \mathrm{BL} / 6 \mathrm{~J})$ were obtained from Jackson Memorial Laboratory and were used for experiments at 4-6 months of age $\left(50-70 \mathrm{~g}\right.$ body wt.). ${ }^{125} \mathrm{I}$-Porcine insulin $(60-80 \mu \mathrm{Ci} / \mu \mathrm{g})$ was prepared by the chloramine- $\mathrm{T}$ method [10]. ${ }^{125} \mathrm{I}-\mathrm{hGH}(100 \mu \mathrm{Ci} / \mu \mathrm{g})$ was prepared by the lactoperoxidase method [11], and purified on a Sephadex G-75 column to yield a peak of monomeric (Mol. Wt. 22 000) ${ }^{125}$ I-hGH.

Acutely isolated adipocytes were obtained using a modification of the method of Marshall et al. [4]. Mice were killed by decapitation and subcutaneous, perirenal and parametrial adipose tissue was removed. Adipose tissue was added to low glucose $(5.6 \mathrm{mM})$ DMEM containing $0.25 \mathrm{mg} / \mathrm{ml}$ collagenase (type 1) (Worthington), $25 \mathrm{mM}$ Hepes, and $40 \mathrm{mg} / \mathrm{ml} \mathrm{BSA}$ (fatty acid free) (Boehringer-Mannheim), ( $\mathrm{pH} 7.4$ ) in a total volume of $4 \mathrm{ml}$ in polypropylene vials. The tissue was finely chopped, gassed with $5 \% \quad \mathrm{CO}_{2} / 95 \% \quad \mathrm{O}_{2}$ and shaken gently $(100 \mathrm{rpm})$ at $37^{\circ} \mathrm{C}$ for $1 \mathrm{~h}$. The adipocytes were then filtered through nylon mesh and washed three times in DMEM/1\% BSA (pH 7.4). The washing procedure consisted of allowing adipocytes to float to the surface in $50 \mathrm{ml}$ culture tubes, and then removal, by suction, of the infranant below the cells. Cell numbers were determined using a hemocytometer and a scaled objective lens.

Mild digestion of ob/ob mouse adipose tissue resulted in a yield of $4.93 \pm 0.26 \cdot 10^{6}$ cells /mouse $(n=84)$ corresponding to approx. 300000 cells $/ \mathrm{g}$ of adipose tissue. Adipocytes from ob/ob mice are significantly larger than adipocytes from other rodents, and hence $\mathrm{ob} / \mathrm{ob}$ mice have a lower number of fat cells per gram of adipose tissue (approx. $1 \cdot 10^{6}$ cells $/ g$ ) [12]. The isolation procedure used in this study therefore produces a reasonably high yield of cells. To determine the metabolic viability of the freshly isolated adipocytes, $\left[{ }^{14} \mathrm{C}\right]$ glucose oxidation was determined, in the presence or absence of $1 \mathrm{mU} / \mathrm{ml}$ porcine insulin (Table I). Adipocytes were prepared as described and washed twice in low glucose $(5.6 \mathrm{mM})$ DMEM/1\% BSA $(\mathrm{pH}$ 7.4). The fresh cells were then aliquoted into $25 \mathrm{ml}$

\section{TABLE I}

Effect of insulin on $D-I^{14}$ Clglucose oxidaton in freshly isolated ob/ob mouse adipocytes

Adipocytes were prepared and preincubated in DMEM/1\% BSA (pH 7.4) for $2 \mathrm{~h}$ at $37^{\circ} \mathrm{C}$. D- $\left[{ }^{14} \mathrm{C}\right]$ Glucose was then added, with or without $1 \mathrm{mU} / \mathrm{ml}$ porcine insulin, and ${ }^{14} \mathrm{CO}_{2}$ production was measured for 1 h. The data represent mean \pm S.E. values for triplicate determinations in 4 experiments. The insulin effect was significant: $P<0.05$, paired $t$-test

\begin{tabular}{lc}
\hline & ${ }^{14} \mathrm{CO}_{2}$ production \\
& $(\mathrm{cpm} / 30000$ cells per $\mathrm{h})$ \\
\hline Basal & $535 \pm 127$ \\
Insulin-stimulated & $1003 \pm 317$ \\
\hline
\end{tabular}

\section{TABLE II}

Effect of RCM-hGH treatment on insulin-stimulated glucose oxidation

The ob/ob mice were treated subcutaneously with saline or RCMhGH $(200 \mu \mathrm{g} /$ day) for 3 days. Adipocytes were then prepared from subcutaneous, perirenal and parametrial adipose tissue and D$\left[{ }^{14} \mathrm{C}\right]$ glucose oxidation was measured in the presence or absence of 1 $\mathrm{mU} / \mathrm{ml}$ porcine insulin. The data represent mean \pm S.E. values for triplicate determinations in 8 experiments. The effect of RCM-hGH was significant: $P<0.025$, paired $t$-test.

\begin{tabular}{ll}
\hline & ${ }^{14} \mathrm{CO}_{2}$ Production \\
& $(\%$ insulin stimulation over basal) \\
\hline Saline-treated & $77.5 \pm 8.3 \%$ \\
RCM-hGH treated & $42.8 \pm 12.3 \%$ \\
\hline
\end{tabular}

flasks ( 300000 cells / flask), gassed with $5 \% \mathrm{CO}_{2} / 95 \% \mathrm{O}_{2}$ and preincubated in low glucose DMEM/1\% BSA (pH 7.4) for $2 \mathrm{~h}$ at $37^{\circ} \mathrm{C}$ in a volume of $2 \mathrm{ml}$. Uniformly labeled $\mathrm{D}-\left[{ }^{14} \mathrm{C}\right]$ glucose $(0.5 \mu \mathrm{Ci} / \mathrm{ml})$ was then added, with or without $1 \mathrm{mU} / \mathrm{ml}$ insulin, and ${ }^{14} \mathrm{CO}_{2}$ production was measured for $1 \mathrm{~h}$. The reaction was terminated by acidification of the medium with $500 \mu 11 \mathrm{M} \mathrm{HCl}$ to release ${ }^{14} \mathrm{CO}_{2}$, and the ${ }^{14} \mathrm{CO}_{2}$ was collected with hyamine hydroxide and counted in a scintillation spectrometer. Insulin concentrations lower than $1 \mathrm{mU} / \mathrm{ml}$ were not used as previous studies have shown that lower concentrations do not yield consistent (significant) stimulation of glucose oxidation in adipose tissue [1] The requirement for high in vitro insulin concentrations to produce significant stimulation of glucose oxidation underscores the well-known intrinsic insulin resistance of peripheral tissues of the ob/ob mouse. Insulin stimulated basal ${ }^{14} \mathrm{CO}_{2}$ production by $75 \pm 19 \%(n=4)$. demonstrating the metabolic viability and responsiveness of the cells.

As noted earlier, treatment of $o b / o b$ mice with $\mathrm{RCM}-\mathrm{hGH}$ resulted in a decreased responsiveness of adipose tissue segments to insulin added in vitro [1]. The development of insulin resistance, however, could not be demonstrated in isolated adipocytes [1]. We therefore decided to reevaluate the induction of insulin resistance by $\mathrm{GH}$ in adipocytes prepared by our much milder cell isolation procedure.

The ob/ob mice were treated subcutaneously with either saline or RCM-hGH ( $200 \mu \mathrm{g} /$ day $)$ for 3 days. On the fourth day, the mice were fasted for $6 \mathrm{~h}$ prior to decapitation. RCM-hGH treatment of these mice increased fasting blood glucose by $58 \pm 18 \%, n=10$. Porcine insulin $(1 \mathrm{mU} / \mathrm{ml})$ stimulated $\left[{ }^{14} \mathrm{C}\right]$ glucose oxidation in adipocytes from saline-treated mice by $77.5 \pm 8.3 \%(n=8)$ (Table II). RCM-hGH treatment significantly decreased the insulin-stimulated response by approx. $45 \%(42.8 \pm 12.3 \%, n=8)$, demonstrating the induction of insulin resistance by GH. RCM-hGH treatment had a variable, but significant, inhibitory effect on basal glucose oxidation $(-34.2 \pm 11.8 \%, n=8)$ 
which was not observed in studies with fat segments $[1,3]$. The reason for this difference is unclear, although it is evident that adipocytes from RCM-hGH-treated animals exhibited enhanced insulin resistance.

Freshly isolated ob/ob adipocytes have also been maintained in primary culture for up to three days. Adipocytes were prepared as described above, except that cells were washed three times in culture buffer (DMEM containing $25 \mathrm{mM}$ Hepes, $20 \mathrm{mM} \mathrm{NaHCO}$, $100 \mathrm{U} / \mathrm{ml}$ penicillin and $100 \mu \mathrm{g} / \mathrm{ml}$ streptomycin $(\mathrm{pH}$ 7.4) following digestion. The ob/ob mouse adipocytes were then suspended $\left(1-5 \cdot 10^{4}\right.$ cells $\left./ \mathrm{ml}\right)$ in culture buffer in a total volume of $70 \mathrm{ml}$ in $250 \mathrm{ml}$ culture flasks. The cells were maintained under a $\mathrm{CO}_{2}$ atmosphere $\left(5 \% \mathrm{CO}_{2}\right.$ in air) at $37^{\circ} \mathrm{C}$. The adipocytes remained floating at the medium surface and did not attach to the culture flasks. At the end of culture, the medium was removed, and the cells were washed (as described above) in $50 \mathrm{ml}$ culture tubes with culture buffer (without penicillin and streptomycin; $\mathrm{pH}$ 7.4).

Binding studies were carried out in triplicate in DMEM (pH 7.4) containing $25 \mathrm{mM}$ Hepes, $20 \mathrm{mM}$ $\mathrm{NaHCO}_{3}, 1 \%$ BSA, ${ }^{125} \mathrm{I}$-hGH $(0.2 \mathrm{ng} / \mathrm{ml}, 30000 \mathrm{cpm})$ or porcine ${ }^{125}$ I-insulin $(2 \mathrm{ng} / \mathrm{ml}, 80000 \mathrm{cpm})$ and approx. $1 \cdot 10^{5}$ cells in a total volume of $500 \mu 1 .{ }^{125} \mathrm{I}-\mathrm{hGH}$ binding $\left(60 \mathrm{~min}\right.$ at $\left.37^{\circ} \mathrm{C}\right)$ and ${ }^{125} \mathrm{I}$-insulin binding $(10$ min at $37^{\circ} \mathrm{C}$ ) were performed under equilibrium conditions. Under these conditions ${ }^{125} \mathrm{I}$-insulin degradation was approx. $10 \%$ (as determined by precipitation with $10 \%$ trichloroacetic acid), and ${ }^{125}$ I-hGH degradation was approx. 4\%. Total cell-associated ${ }^{125} \mathrm{I}-\mathrm{hGH}$ was determined by adding $300 \mu \mathrm{l}$ aliquots of the cell suspension to $100 \mu \mathrm{l}$ dinonyl phthalate oil in a microcentrifuge tube and immediately centrifuging $(10000 \times \mathrm{g}, 30 \mathrm{~s})$ to separate cell-bound ${ }^{125} \mathrm{I}-\mathrm{hGH}$ from free ${ }^{125} \mathrm{I}-\mathrm{hGH}$ in the aqueous medium. The cells floating at the oil-air interface were removed by slicing the top of the tube, through the oil, and cell-bound ${ }^{125} \mathrm{I}-\mathrm{hGH}$ was determined in a $\gamma$-counter. Specific binding was calculated as the difference in binding in the presence (nonspecific binding) and absence (total binding) of an excess (1 $\mu \mathrm{g}$ ) of unlabeled hGH and has been expressed per $10^{5}$ cells as a percentage of the ${ }^{125} \mathrm{I}-\mathrm{hGH} \mathrm{cpm}$ added to each incubation tube. Total cell associated ${ }^{125}$ I-insulin was determined in an identical manner except that nonspecific binding was determined in the presence of $5 \mu \mathrm{g}$ of unlabeled porcine insulin.

During culture in serum-free medium, the cells exhibited marked increases in both ${ }^{125} \mathrm{I}$-insulin binding (5-10 fold) and ${ }^{125}$ I-hGH binding (10-20 fold) (Fig. 1). Due presumably to the trauma of isolation, during the first few hours of culture, there was a significant adipocyte mortality (up to $70 \%$ ) (which has also been seen with rat adipocytes in culture [5]), but thereafter, the light microscopic appearance of the cells and the cell number remained relatively constant. The cells re-

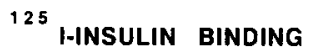

125 I-hGH BINDING

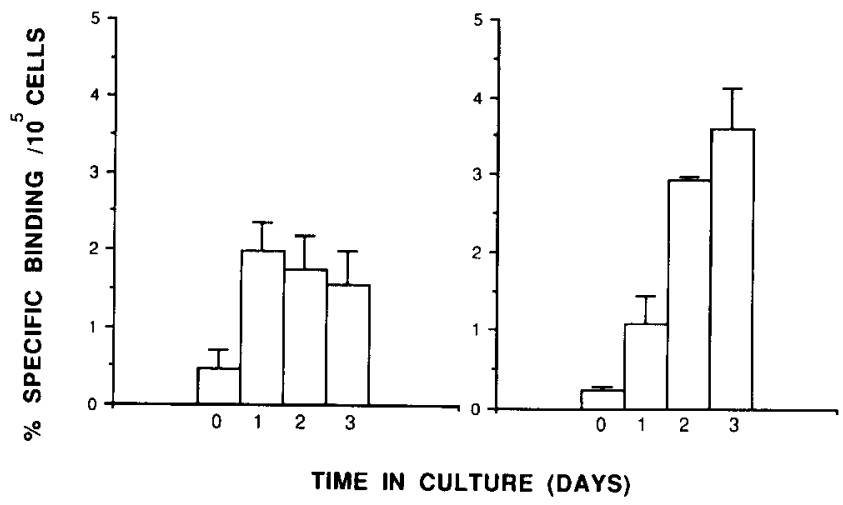

Fig. 1. Effect of culture on porcine ${ }^{125} \mathrm{I}$-insulin and ${ }^{125} \mathrm{I}-\mathrm{hGH}$ binding to ob/ob mouse adipocytes. ${ }^{125} \mathrm{I}$-insulin binding $\left(10 \mathrm{~min}\right.$ at $\left.37^{\circ} \mathrm{C}\right)$ and ${ }^{125} \mathrm{I}-\mathrm{hGH}$ binding $\left(60 \mathrm{~min}\right.$ at $37^{\circ} \mathrm{C}$ ) were performed under equilibrium conditions and are expressed as specific binding (\% of total counts) per $10^{5}$ cells.

mained impermeable to Trypan blue for the duration of the culture, indicating integrity of the plasma membrane.

These results are in agreement with other studies using rat adipocytes in primary culture, in which it has been shown that both insulin binding [4] and $\mathrm{GH}$ binding [5] increase substantially during culture of adipocytes in serum-free medium. The studies with rat adipocytes $[4,5]$ have also shown that these increases in binding during culture are due to an increase in the number of receptors per cell with little or no change in binding affinity, and that the increase in the numbers of receptors is dependent on de novo protein synthesis [5].

It is likely that the increased receptor numbers during culture reflect a release from a down-regulated state induced by endogenous insulin and GH prior to the isolation of ob/ob mouse adipocytes. The high circulating levels of insulin $(400 \mu \mathrm{U} / \mathrm{ml})$ [1] and the levels of $\mathrm{GH}$ achieved after a pulse of $\mathrm{GH}$ in the ob/ob mouse are high enough to induce maximal down regulation of the respective receptors. The down regulation of insulin receptors by physiological levels of insulin has been demonstrated in a variety of cell types [4, 15-19]. Similar studies have shown the down regulation of $\mathrm{GH}$ receptors by GH (reviewed by Roupas and Herington [20]). In addition, many studies of GH binding and insulin binding to cells in culture (either primary or long-term) have been carried out in culture environments dependent on the presence of fetal calf serum. Although fetal calf serum contains significant levels of bovine $\mathrm{GH}$ and insulin, the possible effect of these exogenous hormones on binding studies has been largely overlooked. Cultured ob/ob mouse adipocytes had a markedly stimulated (2-3-fold) basal rate of glucose metabolism, even after a few hours in culture $(4 \mathrm{~h})$, and this effect was observed at all time points tested (up to 
24 h) (data not shown). Due to this high basal rate of glucose metabolism, the cultured cells could not be further stimulated with insulin added in vitro. This phenomenon has also frequently been observed with cultured rat adipocytes [13].

The exact cellular mechanisms by which $\mathrm{GH}$ induces insulin resistance remain largely unknown. For example, it is now well established that the hyperinsulinemia produced in response to the diabetogenic action of $\mathrm{GH}$ does not cause insulin resistance by down-regulating insulin receptors in liver and peripheral tissues (see Ref. 21 for review). Furthermore, it has been demonstrated that $\mathrm{GH}$ does not induce insulin resistance in the ob/ob mouse by altering the ability of insulin to stimulate autophosphorylation of its receptor, indicating that $\mathrm{GH}$ does not alter the ability of insulin receptors to function as tyrosine kinases $[22,23]$. It has recently been proposed that guanine nucleotide binding proteins ( $\mathrm{G}$ proteins) [24-26] may be involved in the signal transduction mechanisms mediating some of the actions of insulin (e.g., via phosphatidylinositol phospholipase C). Recent studies from this laboratory [14] have shown that the in vitro action of insulin on phosphatidylinositol phospholipase $\mathrm{C}$ in ob/ob mouse adipose segments is blocked by pretreatment of the animals with RCM-hGH. This action of insulin on the enzyme is quite rapid (within $5 \mathrm{~min}$ ). Thus, the further dissection of the modulation of this action of insulin on phospholipid metabolism by $\mathrm{GH}$ will require the use of an isolated cell system, in which diffusion barriers are minimized.

This study has described a new method for the isolation of ob/ob mouse adipocytes. These freshly isolated cells are stable, viable and metabolically responsive to insulin. In addition, freshly isolated adipocytes from RCM-hGH-treated mice exhibit enhanced insulin resistance. The availability of this viable and metabolically responsive cell system should now permit detailed studies of the cellular and molecular mechanisms of the induction of insulin resistance by $\mathrm{GH}$.

The authors thank Ingrid Crause for the excellent preparation of the manuscript. P. Roupas is the recipient of a Juvenile Diabetes Foundation International Postdoctoral Fellowship. R.J. Towns is the recipient of a NIH National Research Service Award (DK 07245). This work was supported by KabiVitrum AB, Stockholm, Sweden and was presented in part at the 71 st Annual Meeting of The Endocrine Society, June 1989, Seattle, WA (U.S.A.).

\section{References}

1 Cameron, C.M., Kostyo, J.L., Adamafio, N.A. and Dunbar, J.C. (1987) Endocrinology 120, 1568-1575.

2 Kostyo, J.L., Gennick, S.E. and Sauder, S.E. (1984) Am. J. Physiol. 246, E356-E360.

3 Adamafio, N.A., Kostyo, J.L., Cameron, C.M., Trimark, J.R. and Dunbar, J.C. (1988) Metabolism 37, 900-905.

4 Marshall, S., Garvey, W.T. and Geller, M. (1984) J. Biol. Chem. 259, 6376-6384.

5 Roupas, P. and Herington, A.C. (1986) Mol. Cell. Endocrinol. 47, 81-90.

6 Roupas, P. and Herington, A.C. (1987) Endocrinology 120, 2158 2165.

7 Roupas, P. and Herington, A.C. (1987) Endocrinology 121, 1521 1530.

8 Roupas, P. and Herington, A.C. (1988) Mol. Cell. Endocrinol. 57, 93-99.

9 Cameron, C.M., Kostyo, J.L., Rillema, J.A. and Gennick S.E. (1984) Am. J. Physiol. 247, E639-644.

10 Hunter, W.M. and Greenwood. F.C. (1962) Nature (Lond.) 194. 495-496.

11 Thorell, J.I. and Johansson, B.G. (1971) Biochim. Biophys. Acta $251,363-369$.

12 Johnson, P.R. and Hirsch, J. (1972) J. Lipid Research 13, $2-8$.

13 Garvey, W.T., Olefsky, J.M. and Marshall S. (1986) Diabetes 35 , 258-267.

14 Chou, S.Y., Kostyo, J.L. and Adamafio, N.A. (1990) Endocrinology $126,62-66$.

15 Gavin, J.R. III., Roth, J., Neville, D.M., Jr., DeMeyts, P. and Buell, D.N. (1974) Proc. Natl. Acad. Sci. U.S.A. 71, 84-88.

16 Blackard, W.G., Guzelian, P.S. and Small, M.E. (1978). Endocrinology 103, 548-553.

17 Mott, D.M., Howard, B.V. and Bennett, P.H. (1979) J. Biol. Chem. $254,8762-8767$.

18 Ronnett, G.V., Knutson, V.P. and Lane. M.D. (1982) J. Biol Chem. 257, 4285-4291.

19 Chang, T-H., and Polakis, S.E. (1978) J. Biol. Chem. 253, $4693-$ 4696

20 Roupas, P. and Herington, A.C. (1989) Mol. Cell. Endocrinol. 61, $1-12$.

21 Rizza, .A., Mandarino, L.J. and Gerich, J.E. (1982) Diabetes 31, $663-669$.

22 Kostyo, J.L. (1987) In: Growth Hormone, Basic and Clinical Aspects, Excerpta Medica, Amsterdam, pp. 217-226.

23 Kostyo, J.L., Adamafio, N.A., Cameron, C.M. and Dyszewski, B. (1987) Diabetes 36 (Suppl. 1), 158A.

24 Gawler, D., Milligan, G., Speigel, A.M., Unson, C.G. and Houslay, M.D. (1987) Nature 327, 229-232.

25 Luttrell, L.M., Hewlett, E.L., Romero, G. and Rogol, A.D. (1988) J. Biol. Chem. 263, 6134-6141.

26 Rothenberg, P.L. and Kahn, C.R. (1988) J. Biol. Chem. 263. $15546-15552$ 